\title{
DENTAL AND ORAL CARE TO REDUCE THE INCIDENCE OF VENTILATOR ASSOCIATED PNEUMONIA AMONG PATIENTS WITH VENTILATOR IN INTENSIVE CARE UNIT: A SYSTEMATIC REVIEW
}

\author{
Fiki Kusumasari, Anhari Achadi
}

Masters Program in Public Health, Faculty of Public Health, Universitas Indonesia

\begin{abstract}
Background: Patients in the intensive care unit (ICU) are at risk for dying not only from their critical illness but also from secondary processes such as nosocomial infection. Ventilator-associated pneumonia (VAP) is the second most common nosocomial infection in the ICU and the most common in mechanically ventilated patients. Oral and dental care may reduce microorganisms in the oral cavity. This study was aimed to review the effect of dental and oral care to reduce the incidence of ventilator-associated pneumonia among patients with ventilator in the intensive care unit.

Subjects and Method: A systematic review was conducted by searching published articles from 2014 to 2019, from PubMed. The inclusion criteria were articles in English, full text, randomized controlled trial, and open access. The dependent variable was the incidence of VAP. The independent variable was dental and oral care. After the review process, 8 articles were included in this review.

Results: Eight articles reported that dental and oral care is one of the key factors for VAP prevention. It is an effective procedure to decrease nosocomial infections, colonization of the bacteria, and a tendency to reduce the incidence of VAP.
\end{abstract}

Conclusion: Dental and oral care reduces the incidence VAP.

Keywords: ventilator associated pneumonia, oral care, intensive care unit

\section{Correspondence:}

Fiki Kusumasari. Magisters of Public Health, Faculty of Public Health, Universitas Indonesia, Depok 16424, West Java. Email: fikikusumasari2@gmail.com. Mobile: 081808999608.

\begin{tabular}{l}
\hline BACKGROUND \\
\hline Regulation of the Minister of Health of \\
the Republic of Indonesia Number 27 \\
of 2017 concerning Guidelines for \\
Prevention and Control of Infections in \\
Health Care Facilities states that the \\
type of Healthcare-Associated Infec- \\
tions (HAI) most often occurs in \\
Hospitals (RS) one of which is Venti- \\
lator Associated Pneumonia (VAP). \\
Risk factors for triggers of HAI include \\
the anatomical barrier interruption or \\
form of ventilator use (Ministry of \\
Health, 2017). \\
VAP is a nosocomial infection \\
that occurs after 48 hours of use of
\end{tabular}

Mechanical Ventilation (VM) (Wu et al., 2019). Nosocomial infection is one of the main causes of mortality in critical patients in the Intensive Care Unit (ICU) (Vilela et al., 2015).

Infectious Diseases Society of America (IDSA) and the American Thoracic Society (ATS) report that the VAP mortality rate in America reaches 13\%. Studies in Europe show that the VAP mortality rate in 30 days reached 29.9\%, the initial VAP mortality rate was $19.2 \%$, and the advanced stage VAP mortality was $31.4 \%$. In mainland China, the incidence of VAP reached 23.8\% in 2006-2014 (Wu et al., 2019). 
Numerous studies show the prevalence of VAP in VM patients reaches 9-68\% which causes mortality up to $30-70 \%$. VAP causes longer ICU stay up to 6-7 days, medical costs increase by $\$$ 40,000 per patient, longer VM usage, and increased morbidity, mortality, and patient suffering (Atashi et al., 2018).

The mouth of a patient with VM can function as a reservoir for pathogenic pneumonia in the hospital. VAP prevention interventions are needed to prevent recurrent microaspiration, colonization of pathogenic organisms in the upper respiratory and gas-trointestinal tracts, and ventilator contamination.

Oral pathogen control procedures need to be considered for NP prevention. Many variations of oral care intervention methods in VM patients in the ICU. Basically, there are two ways to remove dental plaque and related microorganisms, namely through mechanical and/ or pharmacological intervention (Vilela et al., 2015).

A series of evidence-based treatments for the prevention of VAP in the ICU were created. PERMENKES No. 27 of 2017 issues seven series of VAP prevention and control, including (1) cleaning hands every time an patient is performed, (2) positioning the bed 30450 if there are no contraindications, such as head and spinal cord injuries, (3) maintain oral hygiene every 2-4 hours with chlorhexidin (CHX) 0.02\% and brush your teeth every 12 hours, (4) management of oropharyngeal and tracheal secretions, (5) assess the use of sedation and extubation every day, (6) administration of peptic ulcer disease prophylaxis in high-risk patients, and (7) administration of Deep Vein Th- rombosis (DVT) prophylaxis (Ministry of Health, 2017).

\begin{tabular}{l} 
SUBJECTS AND METHOD \\
\hline a. Study Design \\
This study is a Systematic review that \\
aims to look at the effects of dental and \\
oral care on the reduced incidence of \\
VAP in VM patients in the ICU. The \\
article search was carried out systema- \\
tically through a single database (Pub- \\
Med) using several keywords stated \\
below. The search involved the term \\
"oral care" OR"dental care" OR "mouth \\
care" OR "dental hygiene" AND "venti- \\
lator associated pneumonia" OR "vap" \\
OR "ventilator \$ acquired pneumonia" \\
OR "nosocomial pneumonia" OR "hos- \\
pital acquired OR "hospital" associated \\
pneumonia "OR" pneumonia "AND" \\
ventilation "OR" ventilator "OR" mv \\
"OR" mechanical ventilation "OR" in- \\
tensive care unit "OR" ICU "pneumo- \\
nia.
\end{tabular}

\section{b. Inclusion and Exclusion Criteria}

Articles must have the following inclusion criteria: (a) published in full-text form in peer-reviewed between 2014 and 2019. (b) use English, (c) performed on critical patients receiving MV in adult ICUs, (d ) patients received dental and oral care either mechanically or pharmacologically while using $\mathrm{MV}$, (f) age of the study population $\geq 16$ years, (g) outcome measures: VAP incidence, and (h) Randomized Controlled Trial (RCT) study design.

\section{c. Data Extraction}

The search was conducted from 27 July to 25 August 2019 independently by one author. The titles and abstracts of all articles are identified to see the relevance of the systematic review topic. Duplicated, irrelevant, non-English, 
and incomplete articles will be excluded from selection. The article is read thoroughly to verify the suitability of the inclusion criteria. Data is made into structured tables and analyzed and conclusions are made based on selected references. Data analysis was made descriptively, without meta-analysis. Data extraction was performed by one writer which included information on the author's name, year, location, country, design or period, study population, inclusion and exclusion criteria, measures of success, control groups, intervention groups, and outcomes. Researchers adhere to the PRISMA guideline standard shown in Figure 1.

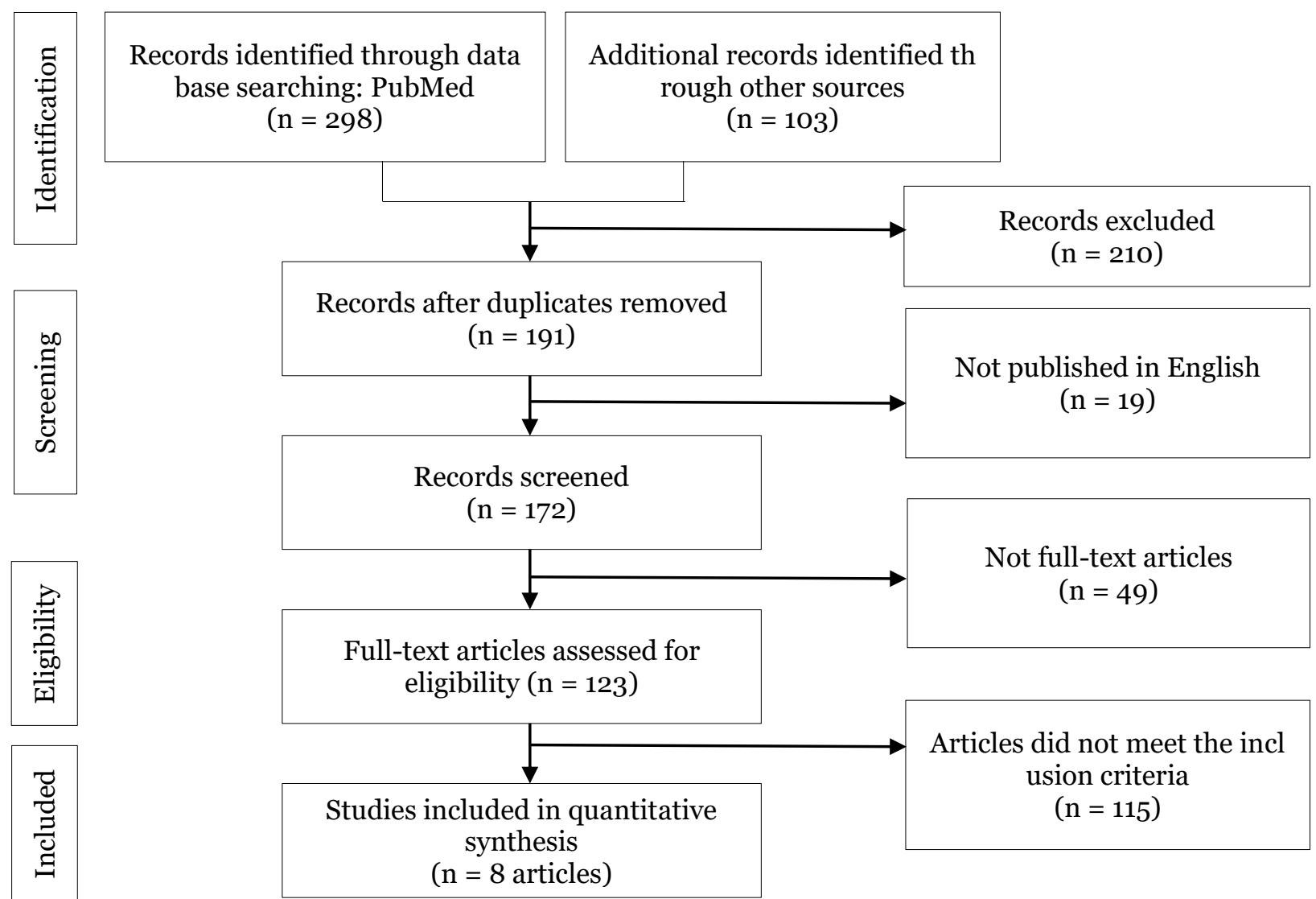

Figure 1. PRISMA systematic review identification, screening, eligibility, and inclusion 
Table 1. Methodological characteristics of the article review

\begin{tabular}{|c|c|c|c|c|}
\hline No & $\begin{array}{c}\text { Title, } \\
\text { Author, } \\
\text { Year, } \\
\text { Journal }\end{array}$ & Purpose & Sampel and Intervention & Results \\
\hline 1 & $\begin{array}{l}\text { Impact of oral } \\
\text { hygiene } \\
\text { involving } \\
\text { toothbrushing } \\
\text { versus CHX in } \\
\text { prevention of } \\
\text { ventilator- } \\
\text { associated } \\
\text { pneumonia: a } \\
\text { randomized } \\
\text { study / } \\
\text { Claudia } \\
\text { Fernanda de } \\
\text { Lacerda Vidal, } \\
\text { dkk / 2017 / } \\
\text { BMC } \\
\text { Infectious } \\
\text { Diseases }\end{array}$ & $\begin{array}{l}\text { To assess } \\
\text { the impact } \\
\text { of tooth } \\
\text { brushing as } \\
\text { a way of } \\
\text { oral care on } \\
\text { the } \\
\text { incidence of } \\
\text { VAP }\end{array}$ & 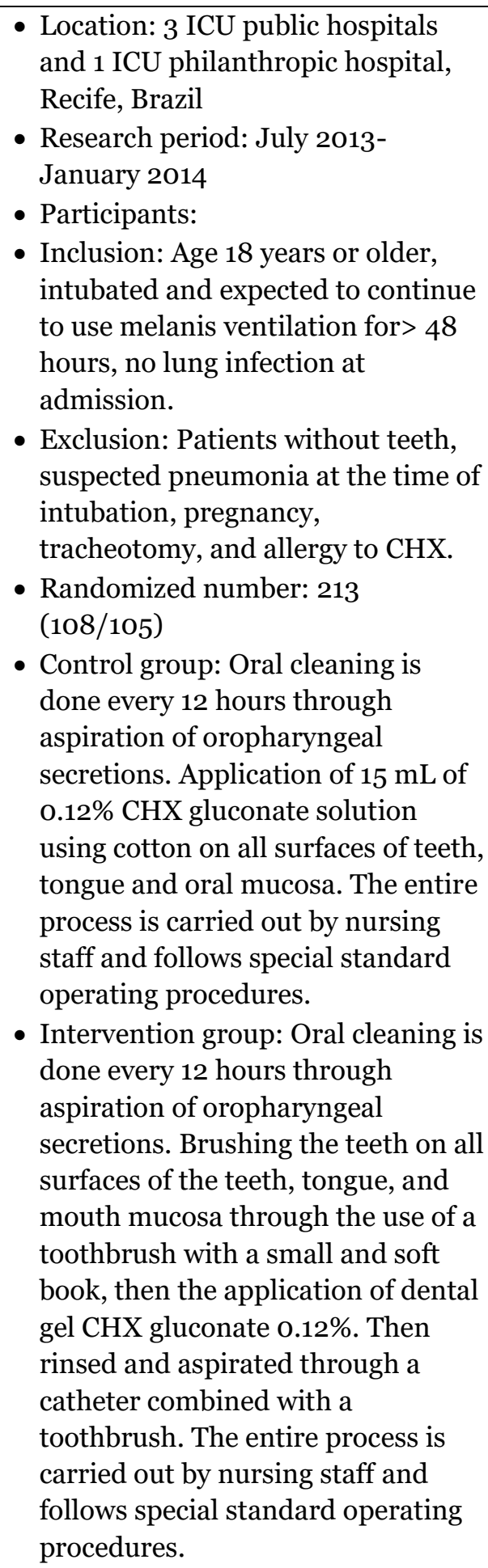 & 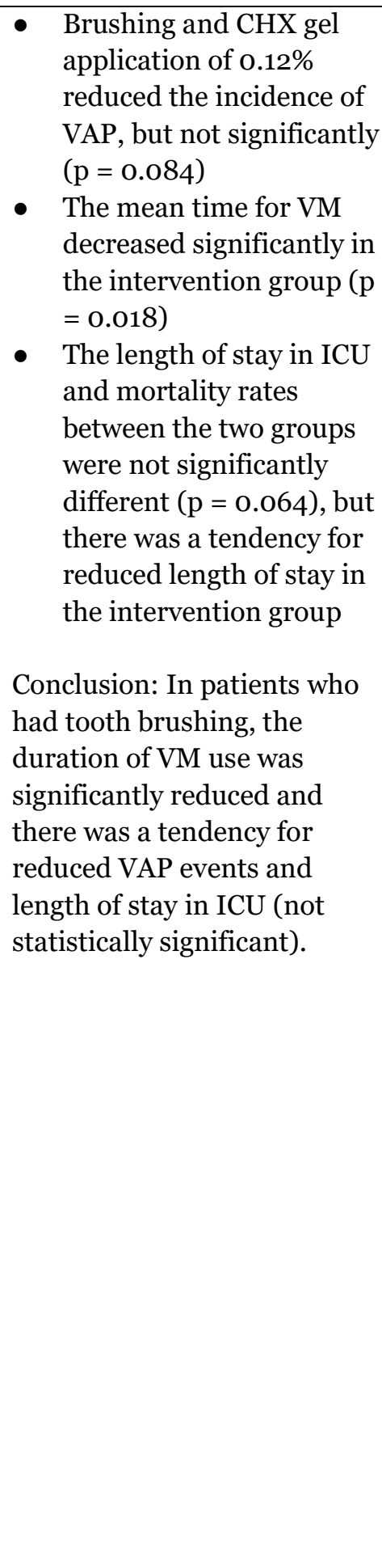 \\
\hline 2 & $\begin{array}{l}\text { Oral } \\
\text { decontaminat } \\
\text { ion }\end{array}$ & $\begin{array}{l}\text { Ipare the } \\
\text { incidence of } \\
\text { VAP in }\end{array}$ & $\begin{array}{l}\text { - Location: Tertiary care center in } \\
\text { South India } \\
\text { - Research period: January } 142014 \text { - }\end{array}$ & $\begin{array}{l}\text { - There was no significant } \\
\text { difference between the } \\
\text { two groups in the }\end{array}$ \\
\hline
\end{tabular}




\begin{tabular}{|c|c|c|c|c|}
\hline & $\begin{array}{l}\text { techniques } \\
\text { and } \\
\text { ventilator- } \\
\text { associated } \\
\text { pneumonia / } \\
\text { Ranjitha } \\
\text { Chacko / } 2017 \\
\text { / British } \\
\text { Journal of } \\
\text { Nursing }\end{array}$ & $\begin{array}{l}\text { ventilator } \\
\text { patients } \\
\text { who brush } \\
\text { their teeth } \\
\text { (with CHX } \\
\text { and } \\
\text { suction) } \\
\text { compared } \\
\text { to } \\
\text { conventiona } \\
\text { l / routine } \\
\text { oral care } \\
\text { (mouth } \\
\text { swabs with } \\
\text { CHX) }\end{array}$ & $\begin{array}{l}\text { December } 27,2014 \\
\text { - Participants: } \\
\text { - Inclusion: Patients who are } \\
\text { ventilated through the orotracheal } \\
\text { tube and intubated in } 4-6 \text { hours, } \\
\text { aged } 16 \text { years and over, receive a } \\
\text { series of VAP treatments (head-end } \\
\text { elevation, antibiotics, H2 receptor } \\
\text { blockers, oral care, hand hygiene, } \\
\text { cleaning tools, and universal } \\
\text { precautions). } \\
\text { - Exclusion: Having a naso-tracheal } \\
\text { tube or tracheotomy, diagnosed } \\
\text { pneumonia on admission, VM } \\
\text { installation outside the institution, } \\
\text { the presence of dentures or few } \\
\text { remaining teeth (less than } 6 \text { teeth), } \\
\text { immunocompromised (absolute } \\
\text { neutrophil less than 500), } \\
\text { prescribed immunosuppressant } \\
\text { drugs, thrombocytopaenia (less } \\
\text { than 50,ooo / mm3), and the } \\
\text { presence of ulcers in the mouth. } \\
\text { - Randomized number: } 212 \\
\text { (106/106) } \\
\text { - Control group: Routine care with } \\
\text { mouth cavity swabs with sponges } \\
\text { soaked in CHX o.2\% } \\
\text { Intervention group: given an oral } \\
\text { care kit with one toothbrush, a } \\
\text { disposable Yankauer suction } \\
\text { catheter, and a disposable syringe. } \\
\text { o.2\% CHX is inserted into the oral } \\
\text { cavity with the help of a syringe. } \\
\text { Lidan and brushed teeth. The oral } \\
\text { cavity was simultaneously sucked } \\
\text { up with a Yankauer suction } \\
\text { catheter. }\end{array}$ & $\begin{array}{l}\text { incidence of VAP ( } \mathrm{p}= \\
\text { o.82). } \\
\text { There is a relationship } \\
\text { between gender ( } \mathrm{p}=\mathrm{o.01} \text { ) } \\
\text { and antibiotic } \\
\text { administration ( } \mathrm{p}=\text { o.01) } \\
\text { on the development of } \\
\text { VAP. } \\
\text { - } \text { Other variables, such as } \\
\text { age, comorbidities, type of } \\
\text { antibiotic, antibiotic-days, } \\
\text { and length of ICU stay } \\
\text { were not related to the } \\
\text { development of VAP. } \\
\text { There is a significant } \\
\text { relationship between the } \\
\text { days of ventilator use and } \\
\text { the development of VAP. } \\
\text { The risk of developing } \\
\text { VAP increases by 1.3x } \\
\text { each day of ventilation. } \\
\text { Conclusion: Early removal of } \\
\text { the ventilator can reduce the } \\
\text { risk of VAP. Tooth brushing } \\
\text { does not reduce the incidence } \\
\text { of VAP compared to regular } \\
\text { oral care. Oral hygiene is one } \\
\text { of the key factors along with } \\
\text { other interventions for the } \\
\text { prevention of VAP. }\end{array}$ \\
\hline 3 & $\begin{array}{l}\text { Effect of Oral } \\
\text { care Program } \\
\text { on Prevention } \\
\text { of Ventilator- } \\
\text { associated } \\
\text { Pneumonia in } \\
\text { Intensive Care } \\
\text { Unit Patients: } \\
\text { A } \\
\text { Randomized } \\
\text { Controlled } \\
\text { Trial / Vajihe }\end{array}$ & $\begin{array}{l}\text { To } \\
\text { determine } \\
\text { the effect of } \\
\text { an oral care } \\
\text { program } \\
\text { based on a } \\
\text { specific } \\
\text { frequency } \\
\text { in VAP } \\
\text { patients in } \\
\text { the ICU }\end{array}$ & $\begin{array}{l}\text { - Location: ICU Hospital affiliated } \\
\text { with Isfahan University of Medical } \\
\text { Science, Iran } \\
\text { - Research period: November 2016- } \\
\text { August } 2017 \\
\text { - Participants: } \\
\text { - Inclusion: Age 18-65 years, } \\
\text { endotracheal tube by mouth, } \\
\text { hospitalization in ICU less than } 24 \\
\text { hours, not hospitalized in other } \\
\text { hospitals before ICU admission, no } \\
\text { history of autoimmune disorders, }\end{array}$ & $\begin{array}{l}\text { There were no significant } \\
\text { differences between the } \\
\text { two groups on the average } \\
\text { CPIS (Clinical Pulmonary } \\
\text { Infection Score) on the } \\
\text { first, third, and fifth days } \\
\text { (p> 0.05) } \\
\text { There were no significant } \\
\text { differences between the } \\
\text { two groups on the } \\
\text { frequency of VAP on the } \\
\text { third and fifth days (p> }\end{array}$ \\
\hline
\end{tabular}




\begin{tabular}{|c|c|c|c|c|}
\hline & $\begin{array}{l}\text { Atashi, dkk / } \\
2018 \text { / } \\
\text { Iranian } \\
\text { Journal of } \\
\text { Nursing and } \\
\text { Midwifery } \\
\text { Research }\end{array}$ & & $\begin{array}{l}\text { pneumonia, or sepsis, non- } \\
\text { pregnant, insensitive on herbs, } \\
\text { there are no dentures, and no oral } \\
\text { or perioral lesions. } \\
\text { - Exclusion: The patient died, was } \\
\text { transferred from the ICU to another } \\
\text { room, the development of severe } \\
\text { oral lesions, and the patient's } \\
\text { guardian chose to withdraw from } \\
\text { the study. } \\
\text { - Randomized number: } 80 \text { (40/40) } \\
\text { - Control group: Routine care is } \\
\text { given by positioning the bed } 300- \\
\text { 45o. The use of swab and } \\
\text { chlorhexidin o.2\% solution every } 12 \\
\text { hours by nurses. } \\
\text { - Intervention group: Oral care is } \\
\text { carried out by two research } \\
\text { assistants who have work } \\
\text { experience at the ICU. Research } \\
\text { assistants receive training needed } \\
\text { for oral care from researchers. The } \\
\text { intervention began on the first day } \\
\text { of ICU admission and continued for } \\
5 \text { consecutive days. The } \\
\text { intervention was carried out with } \\
\text { endotracheal pressures between } 20 \\
\text { and } 25 \text { mmHg using a special } \\
\text { manometer: the position of the } \\
\text { head of the bed } 300-450 ; \text { deep } \\
\text { mouth and throat suctioning; brush } \\
\text { the entire internal and external } \\
\text { surfaces of the teeth, gums and } \\
\text { tongue for two minutes using a } \\
\text { baby toothbrush then using CHX } \\
\text { o.2\%; moisturizing all mucous } \\
\text { surfaces of the mouth, gums and } \\
\text { tongue with swabs and } \\
\text { moisturizing gels containing aloe } \\
\text { vera and peppermint essential oils; } \\
\text { thin application of petroleum jelly } \\
\text { to the lips; remove and clear airway } \\
\text { obstruction; and reinserting the } \\
\text { tube into the patient's mouth. The } \\
\text { frequency of treatment is } \\
\text { determined every } 12,8,6 \text {, and } 4 \\
\text { hours for patients without, mild, } \\
\text { moderate, and severe. }\end{array}$ & $\begin{array}{l}\text { o.05), but the frequency } \\
\text { of pneumonia in the } \\
\text { intervention group } \\
\text { decreased compared to } \\
\text { the control group. } \\
\text { Conclusion: Oral care } \\
\text { programs did not significantly } \\
\text { reduce the incidence of VAP } \\
\text { in critically ill patients } \\
\text { compared to routine oral care } \\
\text { practices. It is necessary to } \\
\text { make a study with a larger } \\
\text { sample and a longer duration } \\
\text { for better results. }\end{array}$ \\
\hline 4 & $\begin{array}{l}\text { The Impact of } \\
\text { Oral Care On } \\
\text { Oral Health }\end{array}$ & $\begin{array}{l}\text { To see the } \\
\text { impact of } \\
\text { oral care on }\end{array}$ & $\begin{array}{l}\text { - Location: ICU Educational Hospital } \\
\text { in Sari affiliated with Mazandaran }\end{array}$ & $\begin{array}{l}\text { Oral health status: } \\
\text { significant differences } \\
\text { between the two groups }\end{array}$ \\
\hline
\end{tabular}




\begin{tabular}{|c|c|c|c|c|}
\hline & $\begin{array}{l}\text { Status And } \\
\text { Prevention of } \\
\text { Ventilator- } \\
\text { Associated } \\
\text { Pneumonia In } \\
\text { Critically Ill } \\
\text { Patients / } \\
\text { Abdullah } \\
\text { Haghighi, dkk } \\
\text { / 2016 / } \\
\text { Australian } \\
\text { Critical Care }\end{array}$ & $\begin{array}{l}\text { oral health } \\
\text { status and } \\
\text { the } \\
\text { incidence of } \\
\text { VAP in ICU } \\
\text { patients }\end{array}$ & $\begin{array}{l}\text { University of Medical Sciences, } \\
\text { Iran. } \\
\text { - Research period: October 2015- } \\
\text { February } 2016 \\
\text { - Participants: } \\
\text { - Inclusion: Intubated during the } \\
\text { study period, ages } 18-65 \text { years, less } \\
\text { than } 12 \text { hours ICU length of stay, no } \\
\text { reintubation, no severe facial and } \\
\text { mouth trauma, no chronic diseases, } \\
\text { no immune disorders, no natural } \\
\text { teeth, does not have lung disease or } \\
\text { pneumonia or sepsis } \\
\text { - Exclusion: The patient died, was } \\
\text { transferred from the ICU, received } \\
\text { a VM in less than } 48 \text { hours, and was } \\
\text { allergic to CHX. } \\
\text { - Randomized number: } 124 \text { (62/62) } \\
\text { - Control group: Brushing your teeth } \\
\text { with toothpaste once a day and } \\
\text { cleaning the mouth using o.2\% } \\
\text { CHX fluid twice a day by a nurse } \\
\text { - Intervention group: Brushing the } \\
\text { internal and external surfaces of the } \\
\text { gums with children's toothbrush } \\
\text { and rotating movements from top } \\
\text { to bottom. Rinse with o.9\% saline } \\
\text { solution, suctioning is done for } 30 \\
\text { seconds. Spray } 5 \mathrm{cc} \text { CHX o.2\% using } \\
\text { a syringe on teeth, tongue, gums } \\
\text { and mucosa followed by suctioning } \\
\text { of the mouth and throat after } 30 \\
\text { seconds. Dampen lips and mouth } \\
\text { with vitamins A \& D. Guedel airway } \\
\text { removed, cleaned, re-paired if } \\
\text { relevant. }\end{array}$ & $\begin{array}{l}\text { occurred on the third day } \\
\text { (p <0.001) } \\
\text { Mucosal-plaque index: } \\
\text { significant differences } \\
\text { between the two groups } \\
\text { occurred on the fifth day } \\
\text { (p <0.001) } \\
\text { The incidence of } \\
\text { pneumonia on the third } \\
\text { and fifth days was no } \\
\text { significant difference } \\
\text { between the two groups } \\
\text { (p = o.538), but the } \\
\text { incidence of the } \\
\text { intervention group was } \\
\text { reduced compared to the } \\
\text { control group } \\
\text { Conclusion: A systematic oral } \\
\text { care program did not } \\
\text { significantly reduce the } \\
\text { incidence of VAP in critically } \\
\text { ill patients compared to } \\
\text { conventional oral care, but } \\
\text { was significant in improving } \\
\text { oral health and the mucosal- } \\
\text { plaque index. }\end{array}$ \\
\hline 5 & $\begin{array}{l}\text { The Effect of } \\
\text { Oral Rinse } \\
\text { With o.2\% } \\
\text { And } 2 \% \text { CHX } \\
\text { On } \\
\text { Oropharyngea } \\
\text { l Colonization } \\
\text { And } \\
\text { Ventilator } \\
\text { Associated } \\
\text { Pneumonia In } \\
\text { Adults' } \\
\text { Intensive Care } \\
\text { Units / Farid }\end{array}$ & $\begin{array}{l}\text { To design } \\
\text { and } \\
\text { implement } \\
\text { oral care } \\
\text { protocols } \\
\text { and } \\
\text { compare } \\
\text { the effects } \\
\text { of two } \\
\text { different } \\
\text { CHX } \\
\text { concentrati } \\
\text { ons on } \\
\text { reducing }\end{array}$ & $\begin{array}{l}\text { - Location: ICU Nemazee Hospital } \\
\text { and Shahid Rajaee, Shiraz } \\
\text { University of Medical Sciences, } \\
\text { Shiraz, Iran } \\
\text { - Research Period: - } \\
\text { - Participants: } \\
\text { - Inclusion: Patients aged } 18 \text { years or } \\
\text { older, have a tracheal tube, use the } \\
\text { VM for } 48 \text { hours, have not been } \\
\text { diagnosed with pneumonia at } \\
\text { admission, have no history of CHX } \\
\text { allergies, do not suffer from } \\
\text { mucosal inflammation or trauma in } \\
\text { the oral cavity, have no immune }\end{array}$ & $\begin{array}{l}\text { In the } 2 \% \text { CHX solution } \\
\text { group there was a } \\
\text { significant reduction in } \\
\text { VAP }(\mathrm{p}=0.007) \text { and } \\
\text { oropharyngeal } \\
\text { colonization }(\mathrm{p}=0.007) \\
\text { compared to the CHX } \\
\text { o.2\% group } \\
\text { There was no significant } \\
\text { difference between the } \\
\text { two groups on the } \\
\text { oropharyngeal adverse } \\
\text { effect (p = o.361) }\end{array}$ \\
\hline
\end{tabular}




\begin{tabular}{|c|c|c|c|c|}
\hline & $\begin{array}{l}\text { Zand, dkk / } \\
2017 \text { / } \\
\text { Journal of } \\
\text { Critical Care }\end{array}$ & $\begin{array}{l}\text { oropharyng } \\
\text { eal } \\
\text { colonization } \\
\text { and VAP in } \\
\text { ICU } \\
\text { patients }\end{array}$ & $\begin{array}{l}\text { disorders, are not experiencing } \\
\text { burns, is not pregnant, and is } \\
\text { treated in the ICU for the first time. } \\
\text { Patients treated for trauma, } \\
\text { surgery, neurological problems, } \\
\text { medical or neurosurgery. } \\
\text { - Exclusion: Patients have obvious } \\
\text { aspiration, diagnosed with } \\
\text { thrombocytopneia and possible } \\
\text { bleeding due to oral care (platelets } \\
\text { <40,ooomm3). } \\
\text { - Randomized number: } 114 \text { (57/57) } \\
\text { Both groups performed the same } \\
\text { steps and were only distinguished } \\
\text { from CHX concentrations (CHX } \\
\text { o.2\% and CHX 2\%) }\end{array}$ & $\begin{array}{l}\text { Conclusion: Oral } \\
\text { decontamination with CHX } \\
2 \% \text { is more effective in } \\
\text { preventing VAP and reduced } \\
\text { oropharyngeal colonization } \\
\text { (especially gram-positive) } \\
\text { compared with CHX 0.2\% }\end{array}$ \\
\hline 6 & $\begin{array}{l}\text { Prospective, } \\
\text { Randomised, } \\
\text { Controlled } \\
\text { Study } \\
\text { Evaluating } \\
\text { Early } \\
\text { Modification } \\
\text { of Oral } \\
\text { Microbiota } \\
\text { Following } \\
\text { Admission To } \\
\text { The Intensive } \\
\text { Care Unit And } \\
\text { Oral Hygiene } \\
\text { With CHX / } \\
\text { Felipe } \\
\text { Francisco } \\
\text { Tuon / 2017 / } \\
\text { Journal of } \\
\text { Global } \\
\text { Antimicrobial } \\
\text { Resistance }\end{array}$ & $\begin{array}{l}\text { To evaluate } \\
\text { the } \\
\text { incidence of } \\
\text { pathogenic } \\
\text { bacteria } \\
\text { related to } \\
\text { VAP and } \\
\text { the scope of } \\
\text { dental } \\
\text { plaque in } \\
\text { the oral } \\
\text { cavity in } \\
\text { patients } \\
\text { given CHX }\end{array}$ & $\begin{array}{l}\text { - Location: University Hospital in } \\
\text { Curitiba, Brazil } \\
\text { - Research period: June } 2014 \text { - } \\
\text { March } 2015 \\
\text { - Participants: } \\
\text { - Inclusion: When admission is } \\
\text { accompanied by VM installation, } \\
\text { age } 18 \text { or older, has a probability of } \\
\text { using VMs> } 48 \text { hours, and } \\
\text { permanent teeth (anterior and } \\
\text { posterior) } \\
\text { - Exclusion: Failure to give written } \\
\text { consent, hospitalization> } 24 \text { hours, } \\
\text { recent use of antibiotics (<1 week), } \\
\text { admission to another hospital or } \\
\text { emergency room in the near future, } \\
\text { and suspected infection in the } \\
\text { upper or lower respiratory tract. } \\
\text { - Randomized number: } 16 \text { (8/8) } \\
\text { - Control / Placebo group: Patients } \\
\text { are cleansed with o.9\% NaCl } \\
\text { solution } \\
\text { - Intervention group: Patients are } \\
\text { cleansed with a } 2 \text { ML CHX solution } \\
\text { mixed with } 15 \text { ML by the nursing } \\
\text { team. The CHX solution is gently } \\
\text { brushed to the gums, mucosa, and } \\
\text { tongue twice a day until it exits the } \\
\text { ICU }\end{array}$ & $\begin{array}{l}\text { When ammunition, multi-drug } \\
\text { resistant (MDR) bacteria are } \\
\text { reported, including } \\
\text { carbapenem-resistant } \\
\text { Klebsiella pneumoniae. } \\
\text { - The intervention group had } \\
\text { a lower incidence of } \\
\text { methicillin-resistant } \\
\text { Staphylococcus aureus } \\
\text { (MRSA) compared to the } \\
\text { control group (p = o.o11). } \\
\text { Strains showed low MICs } \\
\text { (Minimum Inhibitor } \\
\text { Concentrations) and MBCs } \\
\text { (Minimum Bactericidal } \\
\text { Concentrations) in the } \\
\text { intervention group } \\
\text { (<0.039mg / mL) } \\
\text { Conclusion: MDR bacteria } \\
\text { quickly colonized dental plaque } \\
\text { and CHX were able to reduce the } \\
\text { incidence of S. aureus } \\
\text { colonization. }\end{array}$ \\
\hline 7 & $\begin{array}{l}\text { Evaluating } \\
\text { The Efficacy } \\
\text { of Nanosil } \\
\text { Mouthwash } \\
\text { On The }\end{array}$ & $\begin{array}{l}\text { To } \\
\text { investigate } \\
\text { the } \\
\text { preventive } \\
\text { effects of }\end{array}$ & $\begin{array}{l}\text { Location: ICU Amin Hospital, } \\
\text { Isfahan University of Medical } \\
\text { Sciences, Iran } \\
\text { - Research period: November } 2016 \text { - } \\
\text { May } 2017\end{array}$ & $\begin{array}{l}\text { In both groups, the mean } \\
\text { scores of SOFA } \\
\text { (Sequential Organ Failure } \\
\text { Assessment) and GCS } \\
\text { (Glasgow Coma Scale) }\end{array}$ \\
\hline
\end{tabular}




\begin{tabular}{|c|c|c|c|c|}
\hline & $\begin{array}{l}\text { Preventing } \\
\text { Pulmonary } \\
\text { Infection In } \\
\text { Intensive Care } \\
\text { Unit: A } \\
\text { Randomized } \\
\text { Clinical Trial } \\
\text { / Bahareh } \\
\text { Khaky, dkk / } \\
\text { 2018 / Med } \\
\text { Arch }\end{array}$ & $\begin{array}{l}\text { the oral } \\
\text { decontamin } \\
\text { ation } \\
\text { program by } \\
\text { Nanosil } \\
\text { mouthwash } \\
\text { on the } \\
\text { incidence of } \\
\text { VAP }\end{array}$ & $\begin{array}{l}\text { - Participants: } \\
\text { - Inclusion: Age 18-70 years, no } \\
\text { trauma to the jaw and face making } \\
\text { it difficult for oral care, having a } \\
\text { tracheal tube, using VM, no } \\
\text { pneumonia at hospital admission } \\
\text { (MCPIS <7) up to } 48 \text { hours after } \\
\text { intubation, and no refusal to use } \\
\text { Nanosil or CHX allergy. } \\
\text { - Randomized number: } 80 \text { (40/40) } \\
\text { - Control group: Application of CHX } \\
\text { o.12\% as much as } 15 \text { mL } 3 x \text { a day, } \\
\text { followed by brushing teeth, } \\
\text { suctioning oral secretion, and } \\
\text { scrubbing the oropharyngeal } \\
\text { mucosa. The method is the same as } \\
\text { the intervention group } \\
\text { - Intervention group: Application of } \\
\text { 15 mL } 3 \text { times daily Nanosil } \\
\text { (hydrogen peroxide and few silver } \\
\text { ions), followed by brushing teeth, } \\
\text { oral suctioning secretion, and } \\
\text { scrubbing the oropharyngeal } \\
\text { mucosa. The method is the same as } \\
\text { the control group } \\
\text { - Both groups ran a five-day oral } \\
\text { decontamination program }\end{array}$ & $\begin{array}{l}\text { increased significantly on } \\
\text { the fifth day }(\mathrm{p}<\mathrm{0.05}) \\
\text { After five days, the mean } \\
\text { MCPIS score }(\mathrm{p}<0.001) \\
\text { and pneumonia level ( } \mathrm{p}= \\
\text { o.oo8) were significantly } \\
\text { lower in the intervention } \\
\text { group. } \\
\text { - Mortality rates in both } \\
\text { groups are the same (p> } \\
\text { o.o5) } \\
\text { Conclusion: Nanosil is more } \\
\text { effective than CHX to prevent } \\
\text { VAP and reduce the incidence of } \\
\text { VAP in critical patients in the ICU. }\end{array}$ \\
\hline 8 & $\begin{array}{l}\text { Effect of } \\
\text { Oropharyngea } \\
\text { l Povidone- } \\
\text { Iodine } \\
\text { Preventive } \\
\text { Oral Care on } \\
\text { Ventilator- } \\
\text { Associated } \\
\text { Oneumonia } \\
\text { IN Severely } \\
\text { Brain-Injured } \\
\text { Or Cerebral } \\
\text { Hemorrhage } \\
\text { Patients: A } \\
\text { Multicenter, } \\
\text { Randomized } \\
\text { Conrrolled } \\
\text { Trial / } \\
\text { Philippe } \\
\text { Seguin, dkk / } \\
\text { 2014 / Critical } \\
\text { Care Medicine } \\
\text { Journal }\end{array}$ & $\begin{array}{l}\text { To evaluate } \\
\text { the efficacy } \\
\text { and safety } \\
\text { of oral care } \\
\text { with } \\
\text { povidone } \\
\text { iodine } \\
\text { against the } \\
\text { incidence of } \\
\text { VAP in } \\
\text { high-risk } \\
\text { populations }\end{array}$ & $\begin{array}{l}\text { - Location: Six hospitals ICU in } \\
\text { France } \\
\text { - Research period: May } 2008 \text { - May } \\
2011 \\
\text { - Participants: } \\
\text { - Inclusion: All patients over } 18 \text { years } \\
\text { with closed traumatic brain injury } \\
\text { with GCS } \leq 8 \text { and VM are expected } \\
\text { to continue to use } \geq 48 \text { hours } \\
\text { - Exclusion: Oral treatment } \\
\text { procedures cannot be performed } \\
\text { within } 12 \text { hours after endotracheal } \\
\text { intubation and / or have } \\
\text { tetraplegia, facial trauma, } \\
\text { pulmonary contractions involving } \\
\text { more than one lobe, aspiration } \\
\text { pneumonia, current curative } \\
\text { antimicrobial therapy, allergic to } \\
\text { povidone iodine, and pregnant } \\
\text { - Randomized number: } 179 \text { ( } 88 / 91) \\
\text { - Control group: A placebo that is } \\
\text { identical in color, odor and texture } \\
\text { to povidone iodine. } 20 \text { mL placebo }\end{array}$ & $\begin{array}{l}\text { There was no significant } \\
\text { difference between the } \\
\text { two groups on the } \\
\text { incidence of VAP ( } \mathrm{p}= \\
\text { o.69) } \\
\text { There was no significant } \\
\text { difference between the } \\
\text { two groups with } \\
\text { ventilator-associated } \\
\text { tracheobronchitis ( } \mathrm{p}= \\
\text { o.47) } \\
\text { Acute respiratory distress } \\
\text { syndrome occurred in } 5 \\
\text { patients in the } \\
\text { intervention group, but } \\
\text { did not occur in the } \\
\text { control group ( } \mathrm{p}=0.06 \text { ) } \\
\text { There was no difference } \\
\text { between the two groups } \\
\text { on ICU length of stay (p = } \\
\text { o.82) and RS (p = o.35), } \\
\text { and ICU mortality (p = } \\
\text { o.30) }\end{array}$ \\
\hline
\end{tabular}




\begin{tabular}{|c|c|}
\hline $\begin{array}{l}\text { was diluted with } 40 \mathrm{~mL} \text { of sterile } \\
\text { water using a } 60 \mathrm{~mL} \text { syringe. The } \\
\text { solution is injected into the buccal } \\
\text { region and pharyngeal cavity and } \\
\text { suctioned for } 2 \text { minutes regularly } \\
\text { every } 4 \text { hours. The protocol } \\
\text { continues until extubation or until } \\
\text { the } 3 \text { oth day } \\
\text { Intervention group: } 20 \mathrm{~mL} \text { of } 10 \% \\
\text { povidone iodine diluted with } 40 \mathrm{~mL} \\
\text { of sterile water using a } 60 \mathrm{~mL} \\
\text { syringe (final concentration of } \\
3.3 \% \text { ). The solution is injected into } \\
\text { the buccal region and pharyngeal } \\
\text { cavity and suctioned for } 2 \text { minutes } \\
\text { regularly every } 4 \text { hours. The } \\
\text { protocol continued until extubation } \\
\text { or until the } 30 \text { th day before } \\
\text { recruitment, participating nurses } \\
\text { were trained in how to perform oral } \\
\text { procedures. }\end{array}$ & $\begin{array}{l}\text { Conclusion: Povidone iodine } \\
\text { is not effective in preventing } \\
\text { VAP in cases of brain injury or } \\
\text { cerebral hemorrhage and can } \\
\text { increase the incidence of } \\
\text { acute respiratory distress } \\
\text { syndrome. Not recommended } \\
\text { for use to prevent VAP in } \\
\text { high-risk patients }\end{array}$ \\
\hline
\end{tabular}

\section{RESULTS}

Of the initial 401 articles, 8 articles met the criteria set out by systematic review (table 1). Research studies are carried out in several countries. The article consists of two types of research groups, namely the control group and the intervention group.

All articles mention that the reduction in the incidence of VAP cannot be done only with dental and oral care. Most articles show that dental and oral care interventions can reduce bacterial colonization in the oral cavity. All articles show dental and oral care does not reduce the length of stay in the ICU and mortality rates. One article shows the longer the time to use a VM, the greater the risk of VAP.

Two articles show that the combination of two kinds (mechanical and pharmacological) dental and oral care methods have insignificantly different results compared to using only one method (only CHX pharma- cological applications) to reduce the incidence of VAP. The $2 \% \mathrm{CHX}$ concentration is more effective in reducing microbial colonization compared to CHX 0.2\%. Nanosil solution (hydrogen peroxide and few silver ions) has better ability to prevent VAP compared to $\mathrm{CHX}$. The use of povidone iodine solution is not effective in preventing VAP in cases of brain injury or cerebral hemorrhage, but can cause acute respiratory distress syndrome.

\begin{tabular}{l}
\hline DISCUSSION \\
\hline The European Respiratory Society \\
(ERS), the European Society of Inten- \\
sive Care Medicine (ESICM), the Euro- \\
pean Society of Clinical Microbiology \\
and Infectious Diseases (ESCMID) and \\
Asociación Latinoamericana del Tórax \\
(TOOL) issued a management guide for \\
Hospital-Acquired Pneumonia (HAP) \\
and VAP. The guidelines discuss the \\
need for oral and oropharyngeal \\
decontamination. (Torres, et al., 2017).
\end{tabular}


RI Minister of Health Regulation No. 27 of 2017 concerning Guidelines for Prevention and Control of Infections in Health Care Facilities also issues seven series of VAP prevention and control, where one indicator is controlling oral hygiene every 2-4 hours by using CHX $0.02 \%$ antiseptic and teeth brushing every 12 hours once (Ministry of Health, 2017).

VAP is the most common nosocomial infection in VM patients. Microaspiration and biofilm formation in Endotracheal Tube (ET) are the main causes of microbial colonization in the airways that can lead to the development of VAP. Oral biofilms and ET play an important role in the development of pulmonary infections, resistance to treatment, and recurrence of infection in VM patients (Diaconu, et al., 2018). Microorganisms in the oral cavity can move to lower airways during VM use leading to the occurrence of VAP (Sands, et al., 2016).

Control of biofilm formation in ET and oropharyngeal cavities is needed as a VAP prevention strategy. The need to decontaminate is important because some studies show that 48 hours after admission, oropharyngeal colonization by gram-negative bacilli will form an NP etiological agent (Vilela et al., 2015).

Oral decontamination methods are very diverse, the application of $\mathrm{CHX}$ is the first choice in the decontamination process in VM patients in the ICU. CHX is a broad-spectrum cationic antiseptic agent including gram-positive and gram-negative bacteria, such as S. aureus which are resistant to oxacillin and Enterococcus sp. which is resistant to vancomycin. Chemically CHX active- ly works for up to 6 hours (Vilela et al., 2015). CHX application is proven to reduce microbial colonization (Tuon, et al., 2017; Zand, et al., 2017), but it is not statistically significant to reduce the incidence of VAP. CHX concentrations for application also vary from $0.12 \%, 0.2 \%$, and $2 \%$ (Vilela et al., 2015). CHX concentration of $2 \%$ was proven effective in reducing microbial colonization compared to $\mathrm{CHX}$ 0.2\% (Zand, et al., 2017) while CHX 0.2\% was more effective for the prevention of VAP. CHX application twice a day is effective enough to reduce microbial colonization and prevent VAP (Guler \& Turk, 2019).

The combination of two methods (toothbrush and CHX application) is no better in reducing the incidence of VAP than one method (CHX application) (Vidal, et al., 2017). Oral hygiene of patients does not differ greatly between the oral swab or toothbrush method, but nurses state that the toothbrush protocol is easier to apply (Ory, 2017). The tooth brushing method alone does not reduce the incidence of VAP (Camargo, et al., 2019).

The meta-analysis was not carried out due to too varied methodologies, heterogeneity of patient populations, results and assessment methods. The possibility of bias by ICU nurses when applying treatment methods and the least number of study populations. Based on the terms of the systematic review, additional studies are needed to reach more definitive conclusions on the most effective dental and oral care methods, the best frequency of treatment, and optimal concentration of CHX use. 
In conclusion, dental and oral care can reduce biofilm colonization in the oral cavity. Biofilms in the controlled oral cavity tend to reduce the incidence of VAP. The use of CHX becomes the golden standard in an effort to maintain oral hygiene. Dental and oral care is one of a series of effective programs for the prevention of VAP in VM patients. The series of VAP prevention programs are expected to be able to encourage the development of a patient safety culture in hospital ICUs.

\section{REFERENCES}

Sands KM et al. (2016). Microbial profiling of dental plaque from mechanically ventilated patients. Journal of Medical Microbiology, Volume 65 147-159.

Wu D, Wu C, Zhang S, Zhong Y (2019). Risk Factors of Ventilator-Associated Pneumonia in Critically III Patients. Front Pharmacol, 10(482).

Diaconu O, Siriopol I, Polosanu LI, Grigoras I (2018). Endotracheal Tube Biofilm and its Impact on the Pathogenesis of VentilatorAssociated Pneumonia. Journal of Critical Care Medicine, 4(2): 50-55.

Torres A et al. (2017). International guidelines for the management of hospital-acquired pneumonia and ventilator-associated. Eur Respir J, 50.

Ministry of Health (2017). Peraturan Menteri Kesehatan Republik Indonesia Nomor 27 Tahun 2017 tentang Pedoman Pencegahan dan Pengendalian Infeksi di Fasilitas Pelayanan Kesehatan.
Vilela MCN, Ferreira GZ, Santos PS, Rezende NPM (2015). Oral care and nosocomial pneumonia: a sys tematic review. Einstein, 13(2): 290-296.

Tuon FF et al. (2017). Prospective, Randomized, Controlled Study Evaluating Early Modification of Oral Microbiota Following Admission To The Intensive Care Unit and Oral Hygiene With CHX. Journal of Global Antimicrobial Resistance, Volume 8, pp. 159163.

Vidal CFD et al. (2017). Impact of oral hygiene involving toothbrushing versus CHX in prevention of ventilator-associated pneumonia: a randomized study. BMC Infectious Diseases, 17(112).

Chacko R et al. (2017). Oral decontamination techniques and ventilatorassociated pneumonia. British Journal of Nursing, 26(11): 594599.

Atashi V et al. (2018). Effect of Oral Care Program on Prevention of Ventilator-associated Pneumonia in Intensive Care Unit Patients: A Randomized Controlled Trial. Iranian Journal of Nursing and Midwifery Research, 23(6): 486490.

Khaky B, Yazdannik A, Mahjobipoor H. (2018). Evaluating the efficacy of nanosil moutwash on the preventing pulmonary infection in intensive care unit: A Randomized Clinical Trial. Med Arch, 72(3): 206-209.

Haghighi A et al. (2017). The Impact of Oral Care on Oral Health Status and Prevention of Ventilator-Associated Pneumonia in Critically 
Ill Patients. Australian Critical Care, Volume 30: 69-73.

Zand F et al. (2017). The Effect of Oral Rinse With $0.2 \%$ And $2 \%$ CHX on Oropharyngeal Colonization and Ventilator Associated Pneumonia in Adults' Intensive Care Uni. Journal of Critical Care, Volume 40: 318-322.

Seguin P et al. (2014). Effect of Oropharyngeal Povidone-Iodine Preventive Oral Care on VentilatorAssociated Oneumonia IN Severely Brain-Injured or Cerebral Hemorrhage Patients: A Multicenter, Randomized Conrrolled Trial. Critical Care Medicine Journal, 42(1): 1-8.
Guler EK, Turk G (2019). Oral CHX Against Ventilator- Associated Pneumonia and Microbial Colonization in Intensive Care Patients. Western Journal of Nursing Research, 41(6): 901-919.

Ory J (2017). Comparative study of 2 oral care protocols in intensive care units. American Journal of Infection Control, 45(3): 245250.

Camargo L, Silva SN, Chambrone L (2019). Efficacy of toothbrushing procedures performed in intensive care units in reducing the risk of ventilator-associated pneu monia: A systematic review. Journal of Periodontal Research. 